International Journal of Social Science and Economic Research

ISSN: 2455-8834

Volume:06, Issue:03 "March 2021"

\title{
RECENT TRENDS IN INDIAN BANKING SECTOR: CHALLENGES AND OPPORTUNITIES
}

\begin{abstract}
Prasanna. S
Assistant Professor, Department of Economics, R.N., Deshpande Government First Grade College, Mulugundu, Gadag District, Karnataka
\end{abstract}

DOI: 10.46609/IJSSER.2021.v06i03.016 URL: https://doi.org/10.46609/IJSSER.2021.v06i03.016

\begin{abstract}
In recent days banking sector plays a pivotal role in the process of economic development of a country, India is not an exception to this. In India banking sector was well developed system after independence with several sorts of banking were emerged such as public sector banks, foreign banks, private sector banks, regional rural banks and co-operative banks. These banks are providing various sorts of services to the customers by the way of easy transactions of funds at the national and international level, which leads to better performance in other sectors of the country. India had witnessed several innovations in the banking sector since the introduction of globalization, such as Electronic Payment Services, Electronic Funds Transfer, Electronic Clearing Service, Automatic Teller Machine, Point of Sale Terminal, Tele Banking, Electronic Data Interchange, Real Time Gross Settlement, and Card Based System. These services provided by the banking sector create various opportunities in the other sectors of the economy. Despite the faster growth of the banking and its services it is also facing several challenges. The objectives of this paper are to study the recent trends of banking sector in India, to identify the challenges faced and opportunities of banking in the country. The intended study based on the secondary sources of data collected from various books, journals, articles, reports, and websites.
\end{abstract}

Key Words: Banking Sector, Challenges, Trends, Opportunities, Globalization, ATM, RTGS.

\section{Introduction}

In India banking sector plays a predominant role in the process of economic development. The banking system in India most developed than other Asian countries due to unique geographic, social, and economic characteristics. This Banking sector is the section of the economy is associated with keeping financial assets for others, investing financial assets as authority to create more wealth, and the regulation of those activities by government agencies. From an 


\section{International Journal of Social Science and Economic Research}

ISSN: $2455-8834$

Volume:06, Issue:03 "March 2021"

Indian perspective, the banking sector is always been one of the most preferred entrances to employment. In recently this sector is an occupant sector in the Indian economy. It has the possibility to financial credit for over 7.7 of Gross Domestic Product (GDP) over 7,500 billion in market cap, and also to provide more than 1.5 million jobs for a growing population. In a present globalized era in the Indian banking sector has diversified its activities and introduced new products and services that include opportunities in credit cards, consumer finance, wealth management, life insurance, general insurance, investment banking, mutual funds, pensions, fund regulations, stock broking services, custodian services, private equity, etc.

After the nationalization of 14 banks in the country banking sector consists of 26 public sector banks, 20 banks under private banks and 43 foreign banks,61 regional rural banks (RRB's) and more than 90,000 credit cooperatives are working in India. At present Indian banking industry's worth is Rs.81 trillion. These days banking sector working by the way of using technology such as the internet, and mobile devices to provide services and carry out easy truncations through communicating with customers directly. In the above backdrop, the intended study aimed at A Study on Recent Trends in Banking Sector in India Challenges and Opportunities is the need for the study.

\section{Review of literature}

S. Praveen Kumar and J. Pavithra (2017) in their study on Recent Trends in Indian Banking Sector elucidated that, banking sector acts as a backbone of the Indian economy which reflects as a supporter during the period of boom and recession. Further they analyzed that, after 1991 various trends and developments in the banking sector are credited and various reforms were caused to improve their services to satisfy the customers.

Another study made by M.Sujatha, N.V Haritha, and P. Sai Sreeja(2017) A Study on Recent Trends of Banking Sector in India described that, types, the role of the banking sector in the development of the economy, and recent trends in the banking sector such as electronic-cheques, real-time gross settlement, electronic fund transfer, De-mat account, Point of sale.

Seema Malik (2014) in her study on Technological Innovations in Indian Banking Sector: Changed face of Banking traced out that, the more value-added products and services are the innovations in banking and financial sectors such are ECS, RTGS, EFT, NEFT and ATM, Retail banking, Debit and Credit cards, free advisory services, online banking, mobile banking, and many more value-added products and services. 
International Journal of Social Science and Economic Research

ISSN: 2455-8834

Volume:06, Issue:03 "March 2021"

Karigoleshwar (2016) in his study on Emerging Trends in Banking Sector - Its Challenges and Opportunities examines the new trends in commercial banking and the present period the cashless transactions, E-cheques, mobile wallets.

\section{Objectives}

1. To study the recent trends of banking sector in India

2. To identify the challenges faced and opportunities of banking in the country.

\section{Methodology}

The intended study is based on secondary source of data, gathered from various books, articles, census reports, annual reports, Government documents, journals and websites.

\section{Recent Trends in Banking}

\section{Electronic-Cheques}

In the recent trends in the banking electronic cheques is on kind of cheques works same as paper cheques but payment transaction can be done through digital format.XML document provide a mechanism to authenticate parties to make transactions. In e-cheques, signatures are accompanied by the bank-issued certificates which tie with the signer's key to a bank account. Nowadays it is very commonly using by everyone .many of transferring amount transactions can be done through electronic cheques. E-cheques make the easy transfer of payments to customers who are easily available to make payments for online purchases. This declines the chance to cheque bouncing banks always give awareness about their account details when any transaction can be done.

\section{Real-Time Gross Settlement (RTGS)}

RTGS is a fund transfer system, introduced in India in March 2004, is a system through which electronics instructions can be given by banks to transfer funds from the account holders to the other account of the beneficiary of the bank. Under the settlement in the "Real-Time" system, the transactions come about almost right away, and "Gross Settlement "Means that the transaction is settled on one basis unlike national electronic fund transfer (NEFT). Wherever the transaction process occurs in size at a given point in time during the day. The Real-Time Gross Settlement method process regulated and operated under the regulations by the RBI and provides a means of well-organized and quicker money transfer among banks facilitating their monetary operations. 
International Journal of Social Science and Economic Research

ISSN: 2455-8834

Volume:06, Issue:03 "March 2021"

\section{Electronic Funds Transfer (EFT)}

Another important trend in the development of banking in the country is that Electronic Funds Transfer (EFT) is a system whereby anybody those who want to make payment to another person/company etc. A person moves toward his bank and makes a cash payment in other words to provide directions/approval to transfer funds directly from his/her own account to the bank account of the receiver/beneficiary. Entire particulars i.e., the beneficiaries name, his/her bank account number, account type (savings or current account), name of the bank, town, branch name, and so on. Ought to be furnished to the bank at the point of time of requesting, for such transfers so that the sum reaches the beneficiaries' account appropriately and quicker. Reserve Bank of India is the service provider of Electronic Funds Transfers (EFT).

\section{De-mat account}

The Government of India has adopted the de-mat system for electronic storage in the banking sector. The depositary act 1996 reveals that, to maintain shares and securities electronically and eradicating the plight related with as per shares. The main purpose of the introduction of the Demat system is to invest shares and securities each investor ought to have registration. As an alternative of shareholders taking physical fervor of certificates, a De-mat account is opened. It can be provided through stockbrokers. The purpose of purchase, and transfer of shares and their process for sales. There are two types of passwords to access the De-mat account namely Internet password and Transaction password.

\section{Electronic Clearing Service (ECS)}

It is a retail payment method this can be used to make heavy-size payments/receipts of an a like nature, particularly where every individual payment is of a monotonous nature and of a comparatively lesser amount. Under this facility is destined for government departments and companies to create/receive the large size of payments more willingly than for funds transfers by individuals.

\section{Automatic Teller Machine (ATM)}

ATM is known as the Automatic Teller Machine is one sort of the most popular device in India; it is permitted to the customers to withdraw their money 24 hours a day and 7 days a week. The ATM is a tool it allows the customer who has an ATM card to perform habitual banking dealings without interacting with a human teller. Under the system of Automated Teller Machines cash withdrawal, may be used for payment of utility bills, funds transfer between accounts, a deposit of cheques and cash into accounts, balance inquiry, etc. 


\section{Financial technology firms}

It is the latest technology and modernism in the banking sector aimed at competing with traditional monetary methods in the delivery of financial services. The foremost intend of Financial technology is to give technology and finance to start-ups and to augment the practice of financial services for existing financial companies. For the Purposes of computerization of insurance, trading, and risk management, financial technology is used for firms. Banks are collaborating with fine-tech firms to put up an atmosphere those mixtures the modernism of customers. Fine tech firms have entered the industries with the innovation of products and services and targeting the most profitable segments, Showing their inventive commitments and caper contributions. Fine-tech firms have started acquiring customers from traditional banks due to lack and favorable environments for innovation are finding it hard to compete with them. The primary key intention of fin-tech is to provide a lack of leadership support, regulatory budges, cultural and infrastructure limitations are hampering in-house innovation banks.

\section{Point of Sale Terminal}

Another trend and innovation in the banking sector in India are the Point of Sale Terminal. This is a processor fatal service to facilitate is connected online to the computerized customer information files in a bank and magnetically encoded plastic transaction card that identifies the customer to the computer. Throughout a transaction, the customer's account is debited and the retailer's account is credited by the computer for the amount of purchase.

\section{Tele Banking}

It facilitates the customer in the banking sector to do the whole non-cash associated with banking on the telephone. Under the system of Telebanking, Automatic Voice Recorder is used for simpler queries and dealings. For multifaceted queries and transactions, manned phone terminals are used.

\section{Electronic Data Interchange (EDI)}

The Electronic Data Interchange is the electronic exchange of business documents such as purchase orders, invoices, shipping notices, receiving advice, etc. In a standard, computerprocessed, and universally accepted format between trading partners. Electronic Data Interchange may also be used to transmit financial information and payments in electronic form.

\section{Mobile Banking}


International Journal of Social Science and Economic Research

ISSN: 2455-8834

Volume:06, Issue:03 "March 2021"

The extension of internet banking in the county is that, Mobile banking facility. Under this system the bank is in organization with the cellular service providers offers this service. In the Mobile Banking service, mobile phone should either be SMS or WAP enabled. Such kinds of services are available even to those customers with only credit card accounts with the bank.

\section{Challenges faced by the banking sector}

\section{$>$ Customer satisfaction}

In the present day, one of the challenges faced by the banking sector in India is customer satisfaction. These days in the banking sector customers are more value-oriented in their services because they have substitute choices in it. Hence each and every bank has to take care about fulfilling the needs of the customer's satisfaction.

\section{To provide several personnel services}

In current days the most important demanded that banks are to provide several services to enlarge its services, social banking with financial possibilities, mechanization, and groundbreaking mechanization, better customer services, internal supervision and control, sufficient profitability, strong organization culture, etc. Thus banks must be able to provide entire personal service to the customer who comes with hope.

\section{$>$ Competition}

Another challenge faced by the banking sector in India is that the commercial and nationalized banks have faced competition from the new private and foreign banks in the country. Competition in the banking sector brings several challenges ahead of the banks i.e., product positioning, ground-breaking ideas, and channels, and new market trends. In India, banks are controlling their administration by the way of folio converting manpower into machine power. Hence banks are reducing manual powers and most of the work done via machine power in the country. Further skilled and specialized manpower is to be utilized and result-oriented targeted staff will be appointed.

\section{Rural Market}

The challenges faced by the banking sector in the country are fairly mature in terms of product range, supply, and reach, although reach in rural and remote areas in India unmoving remains a defy for both foreign as well as private sectors banks in India. In the form of quality of resources sufficiency and quality of assets, Indian banks are measured to have clean, strong, and clear balance sheets relative to other banks in comparable economies in their region. 
International Journal of Social Science and Economic Research

ISSN: 2455-8834

Volume:06, Issue:03 "March 2021"

\section{Risk management and Financial Consumer Protection}

In the era of globalization protection of customers is another challenge. Right through the scams and pecuniary crisis, the most affected group is the customer. It is the most and worst hit in the crisis. There are numerous biased information issues, lack of transparency in transactions and extra charges with hidden information Product innovations have not focused on customer requirements and have, instead, aimed at serving the interests of the service provider.

\section{Global Banking}

In India, after globalization, there were several multinational and global Banking emerged in the country. As a result of globalization, several foreign and new private banks emerged in India. Hence the domestic nationalized and commercial banks were could not compete against global banking. Thereby sustainable development, one has to agree to a combination process in the form of liberalization and globalization as India spread the red carpet for foreign firms in 1991. The foreign banks operating in India become a major challenge for nationalized and private sector banks. The foreign banks are these banks are huge in size, and forward in technically having a presence in the global market, which provides extra and improved options and services to Indian traders.

\section{Managing Technology}

Rising or acquiring the correct machinery, deploying it optimally, and then leveraging it to the utmost extent is necessary to attain and uphold high service and competence standards while residual cost effectual and delivering the sustainable return to shareholders. Early adopters of technology acquire significant competitive advantages. Hence managing technology is the most challenging for the present Indian Banking Sector.

\section{$>$ Financial inclusion}

Financial inclusion has become essential in today's business environment. Anything is produced by business houses that have to be under the test out from different perspectives i.e., ecological concerns, social and ethical issues, corporate governance. Despite its overpassing, the gap between rich and poor, in India poorer sections are not aware of the banking they were excluding banking facilities. Hence the poor people of the country should be given proper awareness to improving their economic condition. The Reserve Bank of India has introduced various measures for achieving financial inclusion in the country like facilitating no-frills accounts and GCCs for small deposits and credit. 


\section{High Transaction Costs}

Most of the related challenges in front of the banking sector in India are the high transaction cost of moving non-performing assets in their books. The growth led to strains in the operational efficiency of banks and the accumulation of non-performing assets (NPAs) in their loan portfolios.

\section{Opportunities}

\section{Internet Banking}

Internet banking will be provided that online finance it will pick up and there will be raising communication in the form of contributions banking services, insurance, share trading, loans, the based on data warehousing, and data mining technologies. Banking will common anytime and anywhere and will have to upscale, such upscaling could include banks' initiation divide internet banking services aside from conventional banking services.

\section{$>$ Retail Lending}

Presently banks have adopted Retail Lending customer segmentation it has helped the customer in customizing their portfolios well. Hence it becomes a focal point area mainly in the esteem of housing, financing of consumer durables, automobiles, etc., It has also helped in risk scattering and in increasing the income of banks with improved revival rates.

\section{$>$ Rural area customers}

In India, about 70 percent of the whole population contributing a largely unused market for the banking sector. Most of the banking services have entered urban areas but only a few large villages have the banks entered. Hence banks should reach the residual entire villages for the reason that most Indians still live in rural areas.

\section{$>$ Offering various Channels}

It is one of the opportunities for the banking sector in India. In India Banks may offer numerous channels to right of entry their banking and other services i.e., Telephone/mobile banking, ATM, Local branches, Telephone/mobile banking, video banking, etc to augment the banking commerce.

\section{$>$ Good Customer Services}




\section{International Journal of Social Science and Economic Research}

ISSN: $2455-8834$

Volume:06, Issue:03 "March 2021"

For the faster-growing business of the banking sector in India, Good customer services are the best brand ambassador for any bank. Each appointment with a customer is an opportunity to expand a customer's trust in the bank. Whereas rising rivalry customer services has become the stamina for judging the recital of banks.

\section{Indian Customers}

The largest opportunity for the Indian banking sector in the present-day is the Indian customers. Now the Indian customers seek to accomplish his/her way of life aspirations at a younger age with a most favorable mixture of fairness and debt to finance consumption and asset creation. $\mathrm{He} / \mathrm{she}$ represents crossways societies, urban and rural areas. Consumer goods companies are previously tapping this potential it is for the banks to make the most of the opportunity to deliver solutions to this market.

\section{Other Opportunities}

There are a lot of additional opportunities in the future in the field of the Indian banking sector for example to come into new business and new markets, to develop new paths of working, to get better efficiency, to deliver a high level of customer services. Banking deregulation - A rising economy $\bullet$ Increased client borrowing $\bullet$ an increase in the number of banks $\bullet$ an increase in the money supply $\bullet$ Low government-set credit rates $\bullet$ Larger customer checking account balances.

\section{Conclusion}

In the globalized era banking sector plays an important role in the faster and sustainable development of the economy. The up-gradation of technology in banking provides various opportunities in the growing demand for the population in the country. Further, this sector in India is ensuing with enhanced growth in customers. By providing innovative facilities of banks The several changes done by banks are generally focused on financial inclusion for expansion into rural areas and bringing stability by boosting credit growth making banking services near to the customer directly and reducing customer valuable time. Despite the faster growth in the banking sector in the country since globalization, it has also faced several challenges. To overcome these challenges there is a need for services provided to the customer and excluding people in the remote area by involvement in financial inclusion is the need for the future faster development of the Indian economy. 
International Journal of Social Science and Economic Research

ISSN: 2455-8834

Volume:06, Issue:03 "March 2021"

\section{References}

1. Javed Iqbal, Mr. Firdous Ahmad Qazi(2017) Challenges and Opportunities in Indian Banking Sector International Journal of Business and Management Invention, Volume 6 Issue 10.pp-1-4

2. Karigoleshwar (2016) Emerging Trends in Banking Sector - Its Challenges and Opportunities, Scholarly Research Journal for Humanity Science \& English Language,VOL- 6/26,pp7480-7488.

3. Krishna A. Goyal and Vijay Joshi (2012) Indian Banking Industry: Challenges and Opportunities, International Journal of Business Research and Management (IJBRM), Volume (3): Issue (1) p.22-23

4.Praveen Kumar S and J. Pavithra (2017) Recent Trends in Indian Banking Sector, International Journal of Pure and Applied Mathematics Volume 116 No. 18 pp.529-534

5. Savita Sindhu(2018) Emerging Challenges of Indian Banking Sector, International Journal of Engineering Technology Science and Research, Volume 5, Issue 3.p.1053.

6. Seema Malik (2014) Technological Innovations in Indian Banking Sector: Changed face of Banking Volume 2, Issue 6, International Journal of Advance Research in Computer Science and Management Studies pp 122-128

7.Sujatha M, N.V Haritha and P. Sai Sreeja(2017) A Study On Recent Trends of Banking Sector in India, $9^{\text {th }}$ International Conference on Recent Development in Engineering Science,

8. Humanities and Management Mahratta Chamber of Commerce, Industries and Agriculture, Pune India. pp 296-303. 